\title{
Da militância política à constituição do ser professora: memórias revisitadas, histórias entrelaçadas*
}

\author{
Fátima Maria Leitão Araújo' (D) \\ Marcus Aurelio Taborda de Oliveira" (D)
}

\section{RESUMO}

Analisamos a história de vida de quatro educadoras, militantes no combate à ditadura civil-militar brasileira, nos anos de 1960-1970. Por meio de suas memórias buscamos entender suas trajetórias de formação, desvelando as principais influências no que concerne às instituições, ideias e perspectivas presentes em seus processos de formação política. Interessou-nos compreender a definição de suas posturas como mulheres, militantes e profissionais. Utilizando a história oral como suporte empírico, vislumbramos o entrelaçamento de vidas construídas com base em uma teia de sociabilidade na qual confluem instituições como a família, escolas públicas e privadas, Igreja católica, entidades e partidos políticos, universidade e agentes a serviço do estado ditatorial. Depreende-se por meio do estudo que a militância da juventude parece ter-se tornado marca indelével de suas experiências como professoras que creram na transformação da juventude e em seu papel na transformação da sociedade.

\section{PALAVRAS-CHAVE}

história da educação; militância política; vidas de professoras; memórias; educação e ditadura civil-militar.

\footnotetext{
'Universidade Estadual do Ceará, Fortaleza, CE, Brasil.

"Universidade Federal de Minas Gerais, Belo Horizonte, MG, Brasil.

*O artigo é parte dos resultados do projeto Evidências da (auto)formação dos trabalhadores na imprensa: afetando os sentidos, produzindo sensibilidades (entre as décadas finais do século XIX e as iniciais do século XXI). Trata-se da pesquisa de pósdoutoramento realizada entre 2018 e 2019 por Fátima Maria Leitão Araújo no Programa de Pós-Graduação em Educação: Conhecimento e Inclusão Social, da Universidade Federal de Minas Gerais, com a supervisão de Marcus Aurelio Taborda de Oliveira.
} 


\title{
FROM POLITICAL MILITANCY TO BECOMING A TEACHER: REVISITED MEMORIES, INTERTWINED (HI)STORIES
}

\begin{abstract}
This article aims to analyze the life story of four female teachers, who were political militants against the Brazilian civil-military dictatorship in the 1960s and 1970s. Through their memories, we try to understand their school and academic trajectories, unveiling the main social institutional influences, ideas, and perspectives presented in their political formation process. Also, we aim to understand the definition of their roles as women, militants, and teachers, connecting the past and the present. We used oral history as empirical support, highlighting their life trajectories and observing the connection between family, public and private schools, Catholic Church, political parties, universities, and dictatorship agents. We conclude that political militancy during the teachers' youth period is an indelible aspect of their experiences, considering that they believed in youth transformation and their role in the changing society.

\section{KEYWORDS}

history of education; political militancy; teachers' lives; memories; education, and dictatorship.
\end{abstract}

\section{DE LA MILITANCIA POLÍTICA A LA CONSTITUCIÓN DE SER MAESTRA: MEMORIAS REVISADAS, HISTORIAS ENTRELAZADAS}

\section{RESUMEN}

El artículo tuvo como objetivo analizar la historia de vida de cuatro educadoras activistas contra la dictadura brasileña, en los años 1960-1970. Comprendemos sus trayectorias de formación escolar y académica, revelando las principales influencias con respecto a las instituciones sociales, ideas y perspectivas presentes en su formación política. Además, buscamos comprender la definición de sus posiciones como mujeres, activistas y profesionales, creando vínculos entre el pasado y el presente. La historia oral fue el soporte empírico, el estudio de sus trayectorias es el enfoque elegido. Visualizamos el entrelazamiento de vidas desde una red en la que convergen institución familiar, instituciones escolares públicas y privadas, iglesia católica, entidades y partidos políticos, universidad y agentes del estado dictatorial. Se deprende que el activismo juvenil parece haberse convertido en una marca indeleble de sus experiencias como maestras, educadoras que creían en la juventud y en su papel en la transformación de la sociedad.

\section{PALABRAS CLAVE}

historia de la educación; militancia política; vidas de profesoras; memorias; educación y dictadura militar. 


\section{INTRODUÇÃO}

Em um tempo marcado mundialmente pela retórica da modernização, da urbanização e da industrialização, também a sociedade brasileira passava por significativas transformações políticas, culturais, sociais e econômicas entre as décadas de 1950 e 1960, incluindo a redefinição da sua classe média. Com o fim da Segunda Guerra Mundial, o país assistiu otimista e esperançoso à voga modernizadora, além de ter vivenciado um raro momento de estabilidade política que fazia crer que a democracia poderia se afirmar no país.

Muito embora as condições de vida nas cidades diminuíssem a distância entre homens e mulheres e novas práticas sociais vislumbrassem os novos tempos, ao longo da década de 1950 as distinções entre os papéis masculinos e femininos ainda continuavam nítidas. Assim, "ser mãe, esposa e dona de casa era considerado destino natural das mulheres [...]. A mulher que não seguisse seus caminhos estaria indo contra a natureza" (Pinsk, 2018, p. 609). À mulher cabia, portanto, a responsabilidade pela proteção do lar e, por isso, ela receberia uma educação adequada ao seu papel social, qual seja desempenhar as funções inerentes à educação dos filhos e aos cuidados e atividades domésticas que assegurassem a estabilidade e a harmonia do lar, herança que vinha já dos anos finais do século XIX. No âmbito profissional, desde o fim daquele século, ela havia-se inserido no magistério pois, como professora, tinha a missão de educar as crianças, futuros "soldados a serviço da Pátria", ou fomentar o ethos do trabalho desejado pelo país que se modernizava (Lenharo, 1986, p. 40), sem abdicar dos cuidados com a infância.

Já nos anos de 1960 encontramos outras imagens de mulheres, mostrando o quanto elas transformaram a tradição ao transporem as fronteiras que as prendiam à posição de formadoras do futuro da nação, tornando-se elas mesmas sujeitos ativos na luta contra o autoritarismo e as injustiças sociais. Um amplo arco de realizações femininas em diferentes países significou a abertura dos horizontes para as mulheres em relação à cena pública, não deixando de impactar o Brasil. Do domínio da sexualidade, passando pela ampliação do mercado de trabalho e chegando à luta política, o papel das mulheres amplificou um movimento de renovação cultural de alcance praticamente mundial. As lutas e conquistas das primeiras ondas do movimento feminista pareciam ter, definitivamente, atingido a sua universalização. A complexidade do papel desempenhado pelas mulheres na vida pública extrapolou em muito a sua vinculação com o mundo da educação formal. No entanto, aquela voga de mudanças projetou sobre elas novas realizações atreladas a velhas práticas e preconceitos, sobrecarregando a sua existência com o peso da diferenciação sexual do trabalho. Se as mulheres buscavam autonomia e emancipação, o preço a pagar seria não apenas a redefinição do seu lugar na vida pública, mas também a manutenção da sua atuação no âmbito da vida doméstica.

As mulheres sempre tiveram um papel de destaque na organização da cultura no Brasil, pouco visibilizado pela pesquisa histórica ou educacional até algumas décadas atrás. No período por nós analisado, as mulheres ganharam a cena também pelo transbordamento da sua inserção na política, fosse pelo simbolismo da queima de sutiãs, pela ênfase na liberação dos corpos permitida pelo biquíni e pela 
minissaia ou a pílula anticoncepcional, fosse pela militância engajada em esferas de poder marcadas pelo forte mandonismo masculino, como os partidos políticos ou os grupos autoproclamados revolucionários.

Partindo do pressuposto de que o papel das mulheres era crucial naquele redemoinho de protestos, reivindicações e transformação das sensibilidades que marcou as décadas de 1960 e 1970, perguntamo-nos neste texto sobre as trajetórias de mulheres que se tornaram militantes políticas, personagens presentes de forma direta nos confrontos com o regime brasileiro e que, concomitante e/ou posteriormente aos embates que travaram contra a repressão imposta pelos governos militares, faziam-se professoras/educadoras. Buscamos refletir sobre o seu estatuto profissional inquirindo sobre que posturas e concepções de sociedade e educação foram assumidas no "fazer-se" e ser professora.

As experiências de um tempo, que se misturam e se movimentam por meio das memórias de educadoras que, após quase cinco décadas, expõem momentos cruciais das suas vidas, falam de um passado que se faz distante pela premência do esquecimento ou que se faz presente pela dor, mas também pela satisfação que sentem por perceberem o quanto as suas lutas foram importantes para conquistas posteriores. Ao rememorar, elas veem-se no passado, nos muitos encontros que as suas experiências oportunizaram; refletem sobre o que são hoje e o que de outrora permanece em suas vidas atuais. Seguindo Walter Benjamin (1994, p. 198), “A experiência que passa de pessoa para pessoa é a fonte a que recorrem todos os narradores. E, entre as narrativas escritas, as melhores são as que menos se distinguem das histórias orais contadas pelos inúmeros narradores anônimos".

\section{NAS TRILHAS DA MEMÓRIA}

A tarefa de compreender trajetórias pessoais e profissionais de pessoas “anônimas" pressupõe penetrar no mundo fugidio das subjetividades. Assim, o trato com a linguagem oral, representada por fragmentos fixados pela memória, foi uma escolha metodológica que nos possibilitou trazer à luz representações e realidades que o registro escrito não conseguiu transmitir. Não se trata, aqui, de hierarquizar fontes de natureza diversa, mas de reconhecer a premência do depoimento oral para a construção da memória, sempre fugidia, sempre lacunar, inescapavelmente coletiva, mas com as marcas dos sujeitos que vivenciaram em corpo e alma o que foi a sua forma de estabelecer um "diálogo aberto com o mundo" (Thompson, 1981). A memória, para nós, interessa na sua dimensão ética, uma vez que as ações decorrentes do pensar, do querer e do julgar definem, em relação à dimensão pública, o que é relevante como ação permanente, contínua, de elaboração do passado.

A história oral ajuda-nos a atingir o universo dos esquecidos, aqueles que raramente aparecem nos documentos escritos, também por desafiar o juízo inerente à História tradicional e seus mitos (Thompson, 1992), bem como a "memória oficial”, que ao se pretender hegemônica negligenciou tensões e disputas refletidas e fundamentadas nas relações de poder. Parte dessa "memória oficial", que retorna hoje sob a rubrica da mulher "de família" com forte acento moralista e antipolítico, 
propõe-se a silenciar lutas e negligenciar espaços de expressão política dos sujeitos comuns, neste caso, mulheres professoras, impondo aquilo que deve ser lembrado/ rememorado (Pollak, 1989).

Reconhecendo que se tem tornado mais comum nos últimos anos o recurso das narrativas para a compreensão do fenômeno educativo (Taborda de Oliveira, 2014), colocamos ênfase na perspectiva histórica. Assim, tratamos de trajetórias que puderam ser compreendidas com base nos procedimentos da história oral, devidamente cruzados com outras fontes. Nessa trilha, debruçamo-nos sobre os relatos de mulheres militantes, desvelando lembranças que remetem a tempos politicamente traumáticos, os quais ensejam a possibilidade delicada de seleção do que deve ser lembrado, mesmo que respeitando as possibilidades e os modos particulares de lembrar. Nesse sentido, buscamos a compreensão de um conjunto de quatro experiências/trajetórias que reiteram o encontro entre o individual e o coletivo nas tramas da história de mulheres educadoras militantes. Tratada como uma técnica antes que um método, a história oral permite-nos compreender trajetórias de vida de mulheres estudantes que marcariam o campo educacional brasileiro pela sua peculiar militância política. Adentrando os espaços familiares e de formação escolar das meninas que se tornariam militantes políticas no tempo da ditadura civil-militar inaugurada em 1964, procuramos conhecer os traços mais marcantes das suas trajetórias. Pareceu-nos um exercício necessário para compreender um pouco mais as relações entre educação, ditadura e condição feminina no Brasil.

As entrevistas aqui mobilizadas ocorreram entre os anos de 2015 e 2018. Por opção metodológica, foram realizadas individualmente em datas previamente agendadas e locais escolhidos pelas depoentes/narradoras ${ }^{1}$. O encontro com as depoentes ocorreu com base em informações oriundas de pesquisadores e ex-militantes no meio universitário, além de levantamento prévio em associações e Comissões da Verdade nos estados de Ceará e Minas Gerais, parte do esforço exploratório para a realização da pesquisa que deu origem ao trabalho. Produzimos um roteiro geral de entrevista conforme as orientações de Alberti (1990) e Thompson (1992), já adotado anteriormente por Taborda de Oliveira (2018). Nele privilegiamos os seguintes blocos de informações ou descritores:

- socialização;

- formação intelectual e profissional;

- participações;

- educação e política;

- uma última palavra.

1 As entrevistas foram concedidas à professora Fátima Maria Leitão Araújo. Foram entrevistadas duas educadoras do estado do Ceará: Maria Ruth B. Cavalcante, entrevistada no Centro de Desenvolvimento Humano (CDH), e Helena Serra Azul Monteiro, entrevistada na Universidade Federal do Ceará (UFC), além de duas educadoras do estado de Minas Gerais: Maria Céres Pimenta Spínola Castro, na Universidade Federal de Minas Gerais (UFMG), e Efigênia Maria de Oliveira, em sua residência, em Cabo de Santo Agostinho, estado de Pernambuco. 
As entrevistas foram gravadas e tiveram duração média de 100 a 125 min. Com base na formulação desses descritores gerais, o diálogo foi conduzido de modo a interferir o mínimo possível nas narrativas, uma vez que entendemos que o esforço de produção da memória se dá pelo encadeamento de lembranças que, se por um lado são sempre socialmente encarnadas, manifestam-se justamente nas experiências singulares. Estávamos interessados em informações sobre a sua vida, a sua família, os seus relacionamentos e influências, os seus hábitos, a sua formação e estudos e o seu entendimento sobre educação e política, que se converteram em subcategorias analíticas. Todavia, atentos aos nossos objetivos, não induzimos as depoentes a qualquer direção, apenas deixamos que rememorassem conforme os eventos as afetaram com maior ou menor vigor. Aquilo que aflorou daquele intercâmbio de experiências constituiu parte do material explorado neste artigo. Para muitas das perguntas que tínhamos em mente não obtivemos respostas, mas também fizemos pequenos achados naquele mar de rememorações. Uma vez consolidadas, as entrevistas foram transcritas e passaram por um processo de copidesque. Seguindo os protocolos relacionados à ética em pesquisa, após a conferência do seu conteúdo, todas as convidadas-depoentes assinaram o Termo de Consentimento Livre e Esclarecido (TCLE), anuindo ao uso das suas memórias para fins de pesquisa ${ }^{2}$. Ao fim, se estamos convencidos da importância de reelaborar o passado, sabemos que isso nunca poderá ser feito de perspectivas quantitativas que negligenciem a singularidade da experiência.

Considerando-se o imperativo ético da memória, depreende-se que os depoimentos de mulheres educadoras que foram militantes no combate à ditadura-civil militar brasileira podem contribuir para a ampliação de um processo ainda incomum entre nós, de produção de memória e de redefinição de identidade tanto individual quanto nacional: combater as formas sistemáticas do esquecer (Martins, 2014). Para compreender os significados e a importância que as educadoras atribuem às experiências que vivenciaram em seus processos de sociabilidade, formação e militância, e como estas refletiram e refletem em suas práticas sociais e profissionais, buscamos estímulos nas reflexões de Benjamin (1994) e Thompson (1981) sobre memória, experiência e cultura. Estas, associadas às análises concernentes às bases da prática profissional docente, ajudam-nos a afirmar que a relação das docentes com o saber não se reduziu a uma função mecanicista de transmissão de conhecimentos já constituídos por agências de "legitimação", como universidades, editoras etc. — nem mesmo em regimes autoritários, como bem demarcam Garrido (2020) e Kaufmann (2017), que trataram das experiências chilena e argentina, respectivamente.

A experiência que estrutura a vida social é tudo aquilo que move os indivíduos a conservar-se ou transformar-se constantemente, pois ao longo da sua existência eles são afetados e marcados por diversas situações, que fazem com que reflitam e ajam de uma maneira determinada, sob a pressão das circunstâncias. Nesse exercício do viver, refletem sobre os seus dilemas, a sua postura diante do mundo e as ações

2 Pesquisa submetida ao Comitê de Ética da Universidade Estadual do Ceará (UECE) e aprovada por meio do parecer n. 93492218.0.0000.5534. 
do mundo sobre eles. Em contato com as depoentes/narradoras aqui contempladas, deparamo-nos com experiências que são singulares e denunciadoras do seu lugar social, mas que, ao mesmo tempo, dizem de uma cultura comum (Williams, 2003), dos eventos políticos ora conservadores, ora reacionários, que marcam a cultura política brasileira nos últimos 50 anos. Eventos contra os quais elas se insurgiram.

Ouvir as mulheres que compõem o quadro de sujeitos depoentes deste estudo implicou reconhecer que não é possível "conceber nenhuma forma de ser social independentemente de seus conceitos e expectativas organizadores" (Thompson, 1981). Situamos, portanto, as militantes educadoras protagonistas de histórias que se entrecruzam a despeito das diferenças que as separam não só geograficamente, no que concerne à posição que ocupam em um contexto social permeado por desigualdades. Elas são copartícipes de um tempo repleto de ambiguidades. Tempo não só de contestação, mas também de lutas que põem em xeque valores arraigados que negavam o papel social da mulher. Apresentamos e exploramos nuanças importantes das suas trajetórias formativas e de inserção nos espaços de militância social e política e, acompanhando os caminhos pelos quais se constituíram professoras/educadoras, buscamos destacar as suas concepções de sociedade e educação, as quais elas ainda parecem reter na plenitude da sua vida madura.

\section{AS DEPOENTES, SUAS TRAJETÓRIAS FORMATIVAS E A MILITÂNCIA POLÍTICA: VIDAS QUE SE ENTRELAÇAM}

Quatro mulheres constituem-se em narradoras desta história. Foram meninas nascidas nos anos de 1940, que na sua juventude se engajaram na efervescência dos movimentos ligados à Igreja católica ${ }^{3}$ progressista e aos movimentos estudantis. Três delas pertenciam às classes médias urbanas, tendo uma nascido em meio operário. Pelo teor dos seus depoimentos podemos sugerir que uma consciência crítica aguçada desde cedo se anunciara em suas vidas distintas e singulares. A despeito de se diferenciarem em muitos dos aspectos das suas origens sociais, em relação à "visão de mundo" dos seus familiares e do contexto educacional no qual se deu a sua formação escolar, elas confluem quanto às questões relacionadas às perspectivas de sociedade que as fizeram enfrentar os desafios impostos pelo arbítrio dos tempos ditatoriais em nosso país.

3 De acordo com o relatório final da Comissão da Verdade em Minas Gerais — Volume IV (2018, p. 886): "Nesta época, a Igreja inicia um processo de mudanças que reflete as transformações econômicas, políticas e sociais que ocorrem no País, mais especificamente nas regiões Sul e Sudeste: crescimento industrial, urbanização acelerada e a presença marcante na cena política populista dos movimentos estudantil, sindical e camponês. O que melhor expressa o início de um novo posicionamento da Igreja Católica foi o incentivo dado aos diferentes processos de participação dos leigos nas ações pastorais. Nesse sentido, ganha destaque o movimento da Ação Católica que reunia grupos de jovens de diferentes setores da sociedade brasileira, sob as seguintes denominações: Juventude Agrária Católica (JAC), Juventude Estudantil Católica (JEC), Juventude Independente Católica (JIC), Juventude Operária Católica (JOC) e Juventude Universitária Católica (JUC)”. 
As mulheres aqui mobilizadas subverteriam o "destino natural" das suas mães na sua juventude. Segundo estudos sobre a condição geracional daquele período, as mudanças ali encetadas afetaram as gerações seguintes. Cardoso (2005, p. 93) assevera que essas gerações seriam herdeiras das mudanças provocadas pelos movimentos sociais daqueles anos, que resultaram em transformações na imagem da mulher, "com o feminismo; a liberação sexual; as modificações na estrutura da família; a entronização do modo jovem de ser como estilo de vida; a flexibilização das hierarquias e da autoridade; a construção de novas relações entre o adulto e o jovem e o adulto e a criança”. Cristaliza-se, assim, uma unidade imaginária, a "geração anos 60". Katya Braghini (2015) também ajuda a compreender o lugar do jovem na cultura brasileira do período, sobretudo na política. O ideário de uma mídia que defendia um modelo ideal de jovem "tradicional" contrastava fortemente com a ação irrequieta de uma juventude que se havia descoberto como protagonista. Parte daquela juventude vicejava no movimento estudantil secundarista e universitário e seria fortemente reprimida pelo Estado autoritário. No seu seio, muitas mulheres.

\section{HELENA SERRA AZUL MONTEIRO 4}

Nasceu em Fortaleza, no ano de 1947. Ressalta a figura do avô paterno, intelectual e professor que atuou contra a ditadura de Vargas, como preponderante em sua formação. O seu momento de maior atuação política contra o regime militar ocorreu na Universidade Federal do Ceará (UFC), quando passou a ter contato com a Ação Popular $(\mathrm{AP})^{5}$ e a atuar de forma intensa na defesa dos direitos estudantis.

As figuras do pai e do avô foram peças fundamentais para a valorização e o incentivo das suas escolhas profissionais e das suas posturas ideológicas. Seguindo a tradição familiar, ela estudou no Colégio da Imaculada Conceição ${ }^{6}$. A partir de 1964 fez o primeiro e o segundo ano do curso científico no Colégio São João ${ }^{7}$. Foi nessa instituição que iniciou a sua atuação política por meio do grêmio estudantil. O terceiro ano do curso científico foi realizado no colégio Castelo, instituição que, de acordo com sua afirmação, acolhia os professores ligados ao Partido Comunista Brasileiro (PCB) que eram expulsos da universidade. Esses professores traziam a discussão contra o regime militar para a sala de aula. Foi nesse local onde começou

4 Entrevista realizada em 5 de abril de 2017, na UFC, em Fortaleza.

5 Organização política de âmbito nacional, fundada durante um congresso promovido pela JUC em Belo Horizonte, entre 31 de maio e 3 de junho de 1962. Era integrada basicamente por membros da JUC e da JEC, e seu objetivo era formar quadros que pudessem "participar de uma transformação radical da estrutura brasileira em sua passagem do capitalismo para o socialismo".

6 O Colégio da Imaculada Conceição, da Ordem de São Vicente Paulo, foi fundado no ano de 1865 com o objetivo de educar e abrigar meninas órfãs. Tornou-se referência em educação para a educação de jovens das classes mais abastadas da sociedade cearense. Muitas foram educadas na instituição, até mesmo nomes importantes da história do Ceará, como a escritora Rachel de Queiroz.

7 Instituição de ensino privado, fundada em Fortaleza em 1930 e comprada na década de 1970 por uma grande rede de ensino privado do Ceará. 
a ter os primeiros contatos com a Juventude Estudantil Católica (JEC) e com a AP. Com a conclusão do ensino secundário, ingressou na Faculdade de Medicina. A escolha profissional conflitou com a visão tradicionalista do papel da mulher na sociedade católica fortalezense da época.

Por meio da sua atuação na AP, passou a ter contato com os estudos de Marx, Mao Tsé-Tung e Lênin. Com o recrudescimento da ditadura em 1968, foi perseguida por sua atuação na política e passou a viver na clandestinidade. Nessa condição foi para Pernambuco, onde atuavam as Ligas Camponesas ${ }^{8}$, e estabeleceu-se na cidade de Recife. Em relação ao seu engajamento político, ressalta Helena:

Ação Popular era uma organização que lutava contra a ditadura militar, mas não só contra a ditadura, ela se colocava também na perspectiva de uma sociedade socialista. E aí a gente começa a discutir a questão do modelo da revolução que era o modelo maoísta [...]. Estudamos muitos textos... os clássicos: Marx, Lênin e muita coisa do Mao Tsé-Tung. E a gente achava que o Brasil tinha um modelo mais parecido com a China, pelo número da população e tal. E a AP foi muito maoísta mesmo e, em cima disso, ela chegou a montar uma tática e uma estratégia de luta para o movimento estudantil. Mas isso aí foi acontecendo também simultaneamente com a repressão. Então, por exemplo, eu participei em 67 e $68 . .$. e em 68 quando vem o AI-5 [...]. Até 68 estávamos todos só no movimento estudantil e, lógico, em uma organização que tinha uma outra perspectiva.

Assim, em virtude da sua atuação no Recife, foi presa em 1969, grávida de dois meses. Após dois anos, com a ajuda de um padre, conseguiu o alvará de soltura e voltou para Fortaleza. Em 1973 terminou a faculdade e, durante a sua carreira, passou por dificuldades para conseguir trabalho. A sua atuação política não findou com a graduação. Posteriormente passou a atuar no PCdoB e participou do movimento Diretas Já!. Fez parte da Comissão Nacional da Verdade do Ceará, que investigou a violação dos direitos humanos ocorridos durante o período ditatorial por agentes do Estado. Tornou-se professora do curso de medicina da UFC, atualmente aposentada, e segue atuando como pesquisadora e professora do Programa de Pós-Graduação em Farmacologia daquela universidade. É viúva de um importante militante do PCdoB, conhecido por Chico Passeata, e mãe de dois filhos.

8 Surgidas em 1945 após o fim do governo do presidente Getúlio Vargas (1930-1945), as primeiras Ligas Camponesas, sob a direção do recém-legalizado PCB, tinha como um de seus objetivos obter maior projeção para discussões acerca da situação e das relações agrárias estabelecidas no país naquele período, em que o latifúndio exercia grande influência na política nacional. Foi um dos movimentos mais importantes em prol da reforma agrária e da melhoria das condições de vida no campo, no Brasil. Um filme que se tornou icônico sobre aquela experiência foi Cabra marcado para morrer, de Eduardo Coutinho. Depois de ter as filmagens interrompidas pelo Golpe de 1964, o diretor retomou a gravação em 1981. A película de 1962 retrata o assassinato de João Pedro Teixeira, líder da Liga Camponesa de Sapé, na Paraíba, por ordem de latifundiários. 


\section{MARIA RUTH BARRETO CAVALCANTE ${ }^{9}$}

Nasceu no ano de 1944, no município de Pedra Branca, interior do Ceará. De família influente desse rincão cearense, Ruth ressalta "que já nasceu no coletivo" pela grande quantidade de pessoas que compunham a sua família. Em sua narrativa, informa: "Eu sou de uma família tipicamente nordestina, cearense [...]. O meu pai teve no seu primeiro casamento sete filhos. $\mathrm{E}$ casou com minha mãe e teve mais treze. Então somos uma família de vinte pessoas". Nesse sentido, segundo ela, a dinâmica e a vivência na fazenda de seu pai trouxeram "a possibilidade do contato com vários grupos sociais, compondo sua "essência social" e propiciando desde cedo um "espírito de coletividade" e a convivência comunitária.

O início da sua formação escolar deu-se no grupo escolar da sua cidade natal, no sertão cearense. O segundo segmento escolar de Ruth, já em Fortaleza, foi o colégio da Imaculada Conceição. Em virtude das normas rígidas da instituição, foi expulsa e passou a estudar no Colégio Santa Cecilia, também pertencente à rede de escolas privadas católicas. Nesse colégio sua permanência foi passageira, pois a sua postura de rebeldia novamente motivou uma expulsão. Passou a estudar no Colégio Santa Isabel, instituição na qual começou a ter maior acesso às experiências políticas por meio do contato com a JEC. Destacou-se como liderança do grêmio escolar, e a sua trajetória política e educacional desenvolveu-se por meio do Movimento de Educação de Base (MEB). Nesse movimento exerceu diversas funções: foi professora, supervisora e coordenadora. Concomitantemente à sua participação no MEB, ingressou no curso de pedagogia da UFC, em 1966.

No espaço universitário exerceu maior militância política contra o regime ditatorial. Passou a atuar na AP e ganhou destaque como liderança no Diretório Central de Estudantes (DCE) ${ }^{10}$ em 1968. Sua atuação no mesmo órgão seria um dos motivos do contato com partidos políticos como o $\mathrm{PCdoB}$, que seguia as influências "maoístas" de guerrilha camponesa. Registrou como suas principais referências teóricas à época o dominicano Louis-Joseph Lebret ${ }^{11}$ e Paulo Freire. Foi a primeira mulher na diretoria do DCE e também foi a única que, no Congresso de Ibiúna em 1968, teve prisão preventiva decretada. Segundo ela, "aquele foi um momento

9 Entrevista realizada em 13 de novembro de 2015, no CDH, em Fortaleza (CE). Outros contatos foram feitos entre 2016 e 2017 para a complementação de dados sobre as experiências profissionais. Trabalhos de autoria da professora foram por ela fornecidos para a pesquisa, além de recortes de jornais de entrevistas por ela concedidas.

10 Para Rodrigo Patto Sá Mota (2014, p. 24): "As representações anticomunistas hegemônicas entre os vitoriosos de 1964 distorciam bastante os objetivos dos comunistas e, sobretudo sua real capacidade de influenciar os acontecimentos". Entretanto, embora distorcidos, tais argumentos não eram absurdos, "pois os comunistas detinham faixa de influência importante entre as lideranças estudantis". [...] no movimento estudantil, o grupo mais forte vincula-se à esquerda católica, a chamada Ação Popular (AP), que invariavelmente ocupava a presidência da UNE (Sá Mota, 2014).

11 Padre e economista francês, Lebret foi um dos nomes de maior realce na história da Igreja católica na segunda metade do século XX. Seu nome ganhou projeção em virtude do alerta que deu à Igreja sobre os temas de desenvolvimento global. Teve participação importante no Concílio Vaticano II, entre 1962 e 1965, tendo sido nomeado perito, por indicação de Dom Helder Câmara, em questões de desenvolvimento social. Vale lembrar que Helder Câmara foi atuante conselheiro do Conselho Federal de Educação na década de 1960. 
muito tenso, e a prisão de centenas de lideranças estudantis repercutiu fortemente em todo o país". Ruth foi ainda a primeira mulher a ser presa no Hospital Militar de Fortaleza - o fato de não haver prisão feminina para as presas políticas ajuda a entender a novidade daquela forma de ação na cultura política brasileira. $\mathrm{E}$ foi de lá, do hospital, que ela protagonizou uma das fugas mais comentadas da história recente do Ceará, se não do Brasil. Fez-se passar pela sua irmã e, no horário de visita, ludibriando soldados de todo um quartel, deixou o cárcere. Exilada, viveu no Chile e na Alemanha com seu companheiro e também militante, à época estudante de Medicina, João de Paula Monteiro Ferreira. No exilio alemão nasceu sua primogênita Mariana que, com síndrome de Down, mudou toda a história da mãe. Foi a filha quem inspirou o Centro de Desenvolvimento Humano $(\mathrm{CDH})^{12}$, criado e presidido por Ruth quando do seu retorno ao Ceará após a anistia. Ruth casou pela segunda vez e teve mais dois filhos.

\section{EFIGÊNIA MARIA DE OLIVEIRA ${ }^{13}$}

Efigênia de Oliveira nasceu em 31 de agosto de 1944, em Brumadinho (MG). Filha de uma família de nove irmãos, sendo seis homens e três mulheres, seus genitores foram José Pinto de Oliveira, um trabalhador ferroviário braçal, e Carmelina Paula de Oliveira, dona de casa. Sua mãe sempre a incentivou a estudar. Desde muito jovem Efigênia se interessou pelo ofício de professora, o que a levou, ainda cursando a quarta série, a realizar os exames adicionais a fim de ser admitida na Escola Normal Helena Antipoff, na cidade de Ibirité (MG), na qual ingressou e formou-se professora.

Permaneceu alguns anos ainda naquela cidade, onde começou o ofício que a marcaria para toda a vida - a atuação na educação de jovens e adultos —, embora tenha lecionado também crianças em classes multisseriadas na zona rural. Como a cidade era muito numerosa e o local onde residia não oferecia condições de emprego e trabalho para todos, a família resolveu mudar para Contagem, na região metropolitana de Belo Horizonte. Nessa cidade, seus irmãos já estavam trabalhando em fábricas ali instaladas. Efigênia também se tornaria operária fabril, mas continuaria ministrando aulas à noite, após o expediente na fábrica.

Exercendo a função de alfabetizadora de jovens e adultos, ao mesmo tempo que labutava no chão da fábrica, iniciou a sua militância política. Em Contagem, Efigênia passou a se destacar também como liderança sindical, participando efetiva-

$12 \mathrm{O} \mathrm{CDH}$ é uma instituição voltada para os cuidados com a criança, o jovem, o adulto e o idoso. Sua equipe transdisciplinar foi constituída de profissionais especializados nos processos de desenvolvimento humano, nas dimensões psicológica, física, intelectual, espiritual e sociocultural, com ênfase na reeducação afetiva para a vida, na expansão do nível de consciência e no desenvolvimento moral e ético. Foi fundado em 1981 por Edna Machado de Oliveira, João de Paula Monteiro Ferreira, Maria de Fátima Pereira Diógenes e Maria Ruth Barreto Cavalcante.

13 Entrevista realizada em sua residência em Cabo de Santo Agostinho, região da Zona da Mata de Pernambuco, no dia 4 de dezembro de 2017. 
mente na chamada Greve de Contagem ${ }^{14}$ em 1968, ano em que o general Costa e Silva decretou o AI-5, num momento de forte recrudescimento da ditadura brasileira. Entretanto, ainda que tenham sidos presos e perseguidos inúmeros militantes, entre eles a própria Efigênia, os militares e empresários tiveram que ceder e conceder, em plena ditadura, o aumento de $10 \%$ no salário de todos os trabalhadores, sendo "furada" assim, pela primeira vez, a política de arrocho salarial do período. Mas foi nesse momento que se iniciou a saga de uma perseguida política. Em seu relato, diz Efigênia: "Foi depois de uma greve em Belo Horizonte, dos metalúrgicos, que a gente parou, né... A cidade toda parou, todas as indústrias metalúrgicas, aí eu fui demitida, fui perseguida, fiquei fugindo de um canto para outro, até que um dia eu fui presa”.

Presa em 1976, Efigênia só conseguiu a sua liberdade em 1979. Na prisão, passou a conversar com as outras presas políticas, que eram médicas, advogadas, estudantes, e que em comum possuíam a militância contra aquele regime que havia cerceado a liberdade, a participação popular, a possibilidade de distribuição de riquezas e a democracia que ainda estavam em construção na década anterior. Segundo a depoente, o período que passou presa, apesar de tudo, foi produtivo, pois na prisão as presas políticas tinham acesso a livros. Dessa forma, aproveitou o tempo em que esteve presa para estudar e, junto com as outras militantes, organizar um coletivo. $\mathrm{Na}$ sua memória as leituras e as discussões naquele coletivo amenizaram o horror e as atrocidades próprios do espaço de um presídio. Em 1979, com a Lei da Anistia, saiu da prisão, voltando a Contagem, onde conheceu seu atual marido, um maranhense que, assim como ela, também foi militante, perseguido e preso.

As marcas dos tempos de prisão e perseguições cristalizaram-se em forma de dor revelada pela emoção da entrevistada no momento da recordação: "A gente saía da prisão, mas a prisão não saía da gente, não!”. Parece ter sido muito significativa a sua atuação na militância de esquerda quando jovem, vindo a influenciá-la profissionalmente; pois, no período pós-ditadura, seguiu na profissão docente, atuando na Educação de Jovens e Adultos, hoje na zona rural de Pernambuco. A militância também se cristalizou em ações políticas perante o governo de Miguel Arraes, quando da tentativa de reestabelecer as Ligas Camponesas no estado. Efigênia vive atualmente em seu sítio na cidade de Cabo de Santo Agostinho, com seu companheiro e três filhos.

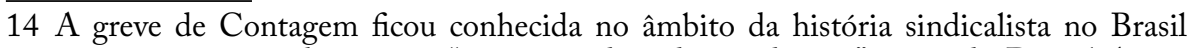
e ocorreu no ano de 1968, o "curto ano de todos os desejos", segundo Daniel Aarão Reis Filho. Para esse historiador: "Osasco e Contagem tornaram-se palavras mágicas, anunciando enfrentamentos apocalípticos”. Algumas assembleias estudantis chegaram a ouvir, eletrizadas, lideranças operárias solicitando apoio. Promoveram-se vendas de bônus, distribuição de panfletos em fábricas e pontos de ônibus, passeatas de solidariedade (Reis Filho, 1998, p. 4). 


\section{MARIA CÉRES PIMENTA SPÍNOLA CASTRO ${ }^{15}$}

Quinta filha de uma família de nove filhos, seis mulheres e três homens, viveu sua infância nas cidades de Capelinha e Bocaiuva. Seu pai foi promotor e depois juiz de direito em Bocaiuva, Montes Claros e Belo Horizonte. A mãe era professora primária em grupos escolares em Bocaiuva e Montes Claros. Desde cedo, a prole foi incentivada a estudar e fazer um curso para poder trabalhar. No entendimento da depoente, naquela época "juiz não ganhava tão bem como ganha hoje”. Nesse sentido, a formação escolar tornava-se necessária para garantir uma vida com menos dificuldades à família. Aos 13 anos começou a militância no movimento estudantil, tentando criar um diretório estudantil no Colégio Imaculada Conceição ${ }^{16}$. Em 1964, com 15 anos de idade e cursando o primeiro ano do curso normal, sentiria os impactos do golpe militar. Nessa época começara a se vincular, com uma irmã um pouco mais velha, à JEC. A sua organização pressupunha a existência da Juventude Estudantil Católica Masculina (JECM) e da Juventude Estudantil Católica Feminina (JECF). O padre que orientava as duas agremiações passou a ser perseguido e foi afastado da escola, fato que as deixaria muito abaladas.

Com a conclusão do curso normal, sua irmã foi morar em Belo Horizonte, onde passou a estudar para ingressar no curso de psicologia. Maria Céres começou a almejar a realização de um curso superior, porém não queria ser professora. Afirmou que não aceitava que o destino profissional das mulheres estivesse restrito ao magistério. $\mathrm{Na}$ sua família, quase todas as mulheres se tornaram professoras, mas ela relatou almejar outra profissão, na qual pudesse trabalhar com questões sociais. Uma freira a quem consultou sugeriu que ela tentasse o curso de serviço social. Fez, então, o vestibular e ingressou no curso de serviço social da então Universidade Católica de Minas Gerais. O pai afirmava que daria às filhas o diploma de normalista e que depois só as ajudaria se isso fosse possível, caso contrário elas teriam de dar aulas para que pudessem manter o seu sustento. Por esse motivo, em fevereiro de 1967, aos 17 anos, ela começou a dar aulas no Grupo Escolar Maria Salomé Pena, no bairro São Bernardo, em Belo Horizonte. No fim do mesmo ano foi efetivada na rede estadual de ensino, por meio de concurso público.

Com o emprego, Maria Céres pôde fazer a faculdade de Serviço Social e pagar suas despesas em uma república estudantil. Durante o dia estudava e à noite dava aulas para turmas de adultos. Nesse período se integrou à AP. Após a conclusão do curso de serviço social, foi contratada como assistente social no Hospital Maria Amélia Lins, antigo Pronto Socorro Policial e depois Hospital João XXIII. Foi presa no fim de 1971, em uma operação que ficou conhecida por Operação Soraia. Após alguns dias na prisão, foi solta e reintegrada às suas funções, respondendo

15 Entrevista realizada no dia 3 de maio de 2018, no campus Pampulha da UFMG, em Belo Horizonte.

16 Colégio da Congregação das Filhas de Jesus, cujas atividades se iniciaram no dia 16 de setembro de 1916, num chalé na cidade de Montes Claros (MG). Desde o início funcionou com salas de Jardim de Infância, Secundário e aulas particulares de bordados. O Colégio Imaculada Conceição oferecia também os cursos especiais de solfejo, canto, francês, espanhol, desenho, pintura, confecção de flores e costura. 
a processo judicial na Justiça Militar, em Juiz de Fora. Foi absolvida em primeira instância e o processo foi encaminhado ao Superior Tribunal Militar.

Casou-se aos 23 anos com um jornalista, também militante. No ano de seu casamento, 1973, assumiu a função de assistente social na Companhia de Saneamento de Minas Gerais (COPASA), tendo de se afastar logo depois por sofrer novo processo criminal, vindo agora de São Paulo, com a decretação da sua prisão preventiva por crimes relativos à Segurança Nacional. Esse processo foi encaminhado ao Superior Tribunal Militar, incorporando-se ao anterior que lá se encontrava. Foi julgado apenas dez anos depois e a decisão foi pela sua absolvição. Mesmo livrando-se da prisão, a demora na finalização do processo fez com que enfrentasse dificuldades e preconceitos.

Tornou-se professora da Universidade Federal de Minas Gerais (UFMG), no Departamento de Comunicação Social. Fez o Mestrado em Educação na mesma universidade (1982) e o Doutorado em Ciências Sociais, na Universidade Estadual de Campinas (UNICAMP) (1994). Em 1997, foi nomeada Secretária Municipal de Educação de Belo Horizonte. Além disso, foi diretora de divulgação e comunicação social da UFMG, Subsecretária de Direitos Humanos da Secretaria de Desenvolvimento Social de Minas Gerais e Secretária Adjunta da Secretaria de Educação do Estado de Minas Gerais. Participou, por nomeação do governo do Estado, da Comissão da Verdade em Minas Gerais durante os anos de 2013 a 2018.

\section{DO REDEMOINHO DE NEBULOSOS TEMPOS À CONSTITUIÇÃO DO SER PROFESSORA/EDUCADORA}

Falar de mulheres em sua atuação política no período da ditadura militar é vislumbrar o universo da "dupla transgressão", termo designado por Ana Maria Colling em seu trabalho As mulheres e a ditadura militar no Brasil (2004). Isso porque os comportamentos das militantes infringiram os códigos de conduta da época, tendo em vista que o lugar primordial da mulher eram a família e o lar, e não a esfera pública e política da sociedade. Sendo assim, o universo que recobre as mulheres e sua atuação política durante a ditadura alude à transgressão de valores ligados ao sexo feminino e à oposição ao governo repressor que se instaurava no Brasil, mesclando elementos de repressão política e perspectivas de "moralização" dos costumes.

Quatro mulheres, trajetórias entrelaçadas, vidas que expressam um tempo intenso nas suas mudanças e desafios. Como milhares de outras mulheres latino-americanas, que viviam a experiência ditatorial, passaram a compreender a estreita relação existente entre as suas vidas e o regime político. Elas transformaram-se em ativistas políticas, saíram do lugar a elas reservado, extrapolando os muros que delimitavam o espaço restrito de atuação do feminino em uma sociedade ainda marcada pelo machismo e mandonismo político patriarcal. Tornaram-se militantes, honrando as saias que vestiam, que ao vento esvoaçavam ao ritmo da coreografia do inconformismo. 
Ao fazer alusão às "saias" nos reportamos ao uniforme característico das escolas femininas, presente no imaginário da nossa sociedade, principalmente no que diz respeito às normalistas. No contraponto às imagens que se construíam sobre o feminino e que se fazem presentes nas histórias desveladas neste trabalho, elas passavam por um momento de transgressão das normas, conceitos e convenções sociais que as aprisionavam em um ideal de mulher a ser seguido. Viviam o momento da minissaia, da liberação e queima do sutiã e da calça comprida, indumentária até então exclusivamente masculina. Além disso, algumas delas enfrentaram a experiência de adotar o "modelo universal do militante" em momento de "formação", que "veio com a dessexualização da militante, que deveria deixar de ser mulher e transformar-se apenas em militante - sujeito universal masculino" (Rosa, 2013, p. 43).

Pelos relatos, constata-se que a influência católica tem presença marcante nas trajetórias formativas das quatro mulheres. Os princípios morais e éticos do catolicismo constituíram bases fundamentais para a militância política das narradoras. A base religiosa que se iniciara no contexto familiar e se cristalizava no seio escolar foi solidificada em fase mais madura, quando elas passaram a ter maior clareza sobre as realidades brasileira e latino-americana no que se refere às desigualdades sociais, econômicas e políticas. $\mathrm{O}$ despertar para os problemas sociais intensificaram-se com o contato que passaram a ter com os princípios do socialismo cristão, nos quais se apoiariam em ações mais incisivas no movimento estudantil. Naquele momento os jovens católicos atuaram de forma mais independente em relação à instituição clerical, passando a deter maior autonomia e assumindo posturas políticas que foram recriminadas e perseguidas pelos segmentos tradicionais da Igreja ${ }^{17}$.

Os movimentos da juventude católica, em especial o da Juventude Universitária Católica (JUC), propunham-se a eliminar a miséria, a fome e a injustiça social, tendo em vista a prosperidade nacional e a dignidade de todos. As ações dos seus militantes foram-se intensificando e já em 1960, poucos anos antes do golpe militar, essa organização estudantil ganhara destaque com a ajuda de partidos políticos, o que propiciaria, em futuro próximo, a atuação dos seus quadros nos partidos políticos ligados à esquerda.

Ainda em 1960, na luta em prol dos direitos humanos, o movimento "jucista" começou a se afirmar fora das diretrizes católicas, sofrendo repressão política. Esse é um dos pontos de referência para pensarmos na formação da AP, movimento no qual a maioria das militantes passou a se inserir. Sendo assim, os movimentos católicos com suas derivações como JEC, JUC e posteriormente a AP foram importantes espaços de formação política e ideológica daquelas meninas e jovens mulheres, cujas histórias são apenas tocadas neste artigo. Destacamos, ainda, nesse contexto repleto de mudanças, rupturas e contradi-

17 Não é demais lembrar que a Igreja católica foi uma das instituições apoiadoras de primeira hora do golpe de 1964 e dos primeiros anos da ditadura. Apenas após o reconhecimento da violência e da lógica persecutória do regime, alguns nomes importantes da cúpula católica passaram a combater os seus arbítrios e dar suporte aos perseguidos pela ditadura. 
ções, a forte presença da pedagogia de Paulo Freire, materializada no MEB. $\mathrm{Na}$ mescla entre pensamento católico, pedagogia freiriana e algumas influências políticas revolucionárias como maoísmo e o leninismo, observamos o hibridismo que movia parte da militância juvenil daquele período. A instituição escolar, a despeito do tradicionalismo e dos princípios rigorosos referentes à formação de mulheres, constituiu lócus propício para as mobilizações estudantis perante a exacerbação do autoritarismo do regime militar, como vem retratando a historiografia (Germano, 2011; Braghini, 2015).

Das quatro narradoras, três (Helena, Ruth e Maria Ceres) mencionam que tiveram atuação na JUC, fato que as levou a uma participação mais expressiva no movimento estudantil, destacando-as como lideranças no meio acadêmico. Com o passar do tempo, as suas ações no movimento juvenil católico foram ganhando proporções mais significativas na militância estudantil, que passou a assumir responsabilidades de ação política como parte do seu compromisso com a juventude, logo com a sociedade brasileira. Esses movimentos foram terreno propulsor da militância política de muitos jovens que ingressaram nas instituições de ensino durante e depois do golpe civil-militar de 1964. Não por acaso, foi a juventude estudantil um dos grupos mais visados e perseguidos pelos órgãos da repressão. Nota-se, mesmo, como a chamada grande mídia disputava os corações e as mentes daqueles jovens, como no caso da Revista Realidade, estudada por Braghini (2014).

Ruth e Efigênia desde cedo passaram a atuar como professoras na educação de jovens e adultos. No caso de Ruth, sua experiência com a pedagogia de Paulo Freire foi definitiva não só para a sua militância como estudante do curso de pedagogia da UFC, mas também marcaria toda a trajetória de vida da autora, ainda hoje ativa. Quanto à Efigênia, sua prática no processo de alfabetização de crianças e trabalhadores rurais, acrescida de sua labuta no chão da fábrica, levou-a ao contato com os movimentos sociais, especialmente o sindicalismo, assim iniciando a militância no movimento sindical e no movimento de bairros. A Escola Helena Antipoff fora o lócus primordial da sua formação profissional e humana, como demonstra a sua fala: "Na época já tinha começado a aprender um pouco de Paulo Freire lá na Helena Antipoff [...] E a gente aprendeu muita coisa com ela, muita coisa... Muitos desses trabalhadores aprenderam a ler e a escrever comigo... que era bem mocinha... dezessete, dezoito anos, e foi aí que eu comecei”.

Enquanto Ruth e Efigênia desde a juventude se embrenharam nos caminhos da docência, seguindo os ditames da formação das alunas das escolas normais, $\mathrm{He}$ lena e Maria Céres nunca alimentaram o desejo de se tornarem professoras. Helena sempre almejou ser médica e teve apoio do seu pai, considerado pela memória da primogênita de três filhas um "homem à frente de seu tempo". Maria Céres foi em busca de outra formação, porém as necessidades para a sua manutenção em Belo Horizonte fizeram-na adentrar as portas da rede pública de ensino do estado de Minas Gerais. Já Helena, depois das agruras enfrentadas como ex-presa política e exilada, ingressou no magistério superior. As duas "professoras improváveis" acabaram por se destacar como pesquisadoras e escritoras acadêmicas. 
No que concerne às experiências no magistério, o que nos dizem essas quatro mulheres sobre as relações entre formação escolar, vivências sociais, militância política e escolha profissional? Que concepções políticas e educacionais nortearam e ainda norteiam suas práticas docentes? Seria possível estabelecer contribuições e influências das vivências na militância política em suas concepções e práticas educativas?

A trajetória profissional de Helena Serra Azul é peculiar no que se refere ao seu encontro com a docência. Após a conclusão do curso de medicina, ela passou por muitos problemas para se inserir no mercado de trabalho. De acordo com o seu depoimento, logo que concluiu o curso houve uma seleção para professor colaborador na UFC, porém ela não teve nem chance de se inscrever, pois tinha que apresentar um "atestado ideológico", o que se tornara impossível em virtude do seu histórico de ex-presa política. Fez especialização, residência médica e doutorou-se em ciências médicas pela UNICAMP. Para Helena, a sua identificação com a área acadêmica a conduziu à docência. Pesquisa e ensino são duas paixões que ainda hoje movem sua vida profissional, mesmo estando ela já aposentada, pois continua contribuindo na pós-graduação. Após sua primeira experiência docente na Pontifícia Universidade Católica (PUC) de São Paulo, realizou concurso para a área de farmacologia clínica, sendo efetivada na UFC em 1991. Sobre o ser professora, assim se expressa:

Desde 91 comecei... aí me envolvi com pesquisa desde essa época, hoje sou pesquisadora do [Conselho Nacional de Desenvolvimento Científico e Tecnológico] CNPq. Oriento dissertação de mestrado e tese de doutorado, e assim, é como eu brinco com o pessoal: "Gente, eu tenho uma formação mais científica, mais técnica, mas eu tenho um posicionamento político, eu tenho um lado [...]”. Mesmo na parte da pesquisa não existe aquela coisa do que não é político, tudo é político. Mesmo a ciência, ela tá dentro do contexto. Então, por exemplo, se eu estudo fármacos, isso aí tem que ser em benefício do desenvolvimento da ciência, mas você não vê a ciência pela ciência. Isso é para a humanidade, né? Para as pessoas [...].

No seu relato, a professora-pesquisadora fez questão de deixar claro aos seus alunos que tem posições políticas. Além disso, nas suas aulas, embora preze pelo rigor em relação aos conteúdos científicos, a sua perspectiva política, que inclui preocupações com a saúde e a sociedade, constitui um elemento fundamental da formação do futuro médico.

Já a trajetória de Ruth Cavalcante nos conduz ao encontro de uma normalista que passa a exercer a docência e outras atividades inerentes à educação logo que conclui o curso normal. A sua professora de Português, Ivone Garcia, que trabalhava no MEB, indicou o nome da jovem normalista para substituí-la. Para Ruth o convite proporcionou o início do fortalecimento da sua identidade como educadora. A experiência no MEB, seu contato com o Movimento de Educação Popular, foram deveras significativos para a sua vida, segundo as suas recordações. 
Era uma equipe altamente capacitada e eu era a mais jovem da equipe e fui escolhida para ser a professora locutora [...] A gente alfabetizava pelo método Paulo Freire. Se o método Paulo Freire alfabetizava em 45 horas, presencialmente, quer dizer, em torno de três meses, pelo rádio a gente alfabetizava em seis, era um sucesso você alfabetizar em seis meses camponeses que nunca tinham ido para a escola.

Ruth ressalta a importância do MEB, que, para ela, era uma verdadeira escola. Tratava-se de uma iniciativa que tinha uma organização em nível nacional, e a educadora orgulha-se de sua passagem pelo Movimento, no qual atuou como professora locutora, supervisora e coordenadora, em Fortaleza. Pela sua imersão nessas atividades, não tinha nenhuma vontade de entrar na universidade. Após três anos de experiências no Movimento, percebeu a importância de fazer um curso superior. Concomitantemente ao trabalho no MEB, passou a cursar Pedagogia na Faculdade de Educação da UFC. Sua militância intensificou-se, então, estando ela na condição de estudante universitária e educadora freiriana. $\mathrm{Na}$ universidade, a principal bandeira era contra a Reforma Universitária e, principalmente, contra os acordos entre o Ministério da Educação e a United States Agency for International Development (MEC-USAID). Com a exacerbação da repressão a partir do AI-5, a vida de Ruth tomaria novos rumos. Ela estava em seu terceiro ano de faculdade e seu compromisso com uma educação libertadora a fizera oferecer cursos sobre o método na Faculdade de Educação, aberto ao público interessado em desenvolver a metodologia de Paulo Freire para a alfabetização. Nas palavras de Ruth: "O AI-5, esse golpe sobre golpe, proibiu Paulo Freire [...]. Então eu fui por cima do partido, não era nem para gente dormir em casa, quanto mais ir para a faculdade [...]. Mas eu tinha o compromisso, nessa hora aí eu não me sentia estudante, eu me sentia uma profissional da Educação que estava dando o curso".

Em um momento no qual foi à faculdade para avisar a turma que não poderia mais continuar o curso, foi surpreendida e presa pela polícia. Depois da fuga passou a viver cladestinamente com seu companheiro, passando os dois por Pernambuco e São Paulo disfarçados de camponeses. Quando a situação se tornou insustentável, foram para o exílio no Chile e, depois, na Alemanha. Já estabilizados, no país europeu ela iniciou o curso de graduação em Psicopedagogia. Lá também nasceu sua filha Mariana, com síndrome de Down, que serviu de inspiração para que a professora e militante buscasse novos conhecimentos e caminhos para o seu desenvolvimento cognitivo e psicossocial. À pedagogia de Freire, que sempre norteara as concepções e práticas educativas de Ruth, mesclaram-se os pressupostos da Educação Biocêntrica. Sobre essa perspectiva, ela teorizou: "É você estar sempre se perguntando: isso que estou fazendo tá gerando vida? $\mathrm{E}$ a vida tem que ser vista a partir daqueles que estão mais necessitados de ter sua vida potencializada, que são os oprimidos, que são os rejeitados, que são os deficientes, que são todos essas pessoas que estão socialmente excluídas". Quanto a ser educadora, assim se define a professora Ruth: 
Eu me defino como um ser que está profundamente inserido no seu tempo. Eu estava inserida naquele tempo, daquela forma. Estou inserida agora neste meu tempo, com esta minha idade, com esta minha experiência, com tudo que tenho. Então eu vivo de fato o lugar onde estou. Eu acho que o Paulo Freire, quando ele diz assim, "que a gente tem que formar o ser no mundo e o ser do mundo", eu meu sinto um ser do mundo, como parte de tudo, e o ser no mundo que é transformador disso. Então no espaço em que eu estou, eu busco isso. Agora busco isso para quê? Para minha satisfação pessoal? Para minha felicidade individual? De jeito nenhum. Eu tenho um compromisso com o coletivo muito grande e acho que todo o espaço social é um espaço de educação aonde quer que estejamos, não é só na sala de aula. Todo espaço gera uma aprendizagem e um desenvolvimento nas pessoas.

Em relação à trajetória de Efigênia Maria de Oliveira, assim como Ruth Cavalcante, ela sempre se identificou com o magistério. Ratificando uma memória comum a muitas professoras, afirmou que desde cedo o seu "sonho" era o de ser professora. Após a conclusão do curso normal em Ibirité, foi morar em Contagem, onde se especializou em Educação de Adultos: "comecei a fazer alfabetização de adultos, porque naquele tempo tinha muito trabalhador que era analfabeto, que mal assinava o nome, quer dizer, bordava o nome, né? Nem sabia o que estava escrevendo". Efigênia narra sua vida permeada de lutas e dificuldades, mas repleta de utopias e disposição para mudar a sociedade. Começou a lecionar ainda no último ano de governo de João Goulart, engajada no sindicalismo fabril e no compromisso político de educar trabalhadores rurais no período noturno. Enfrentaria, com isso, as perseguições no pós-golpe de 1964. Em sua narração, é enfática:

O AI-5 foi a desgraça total. E foi nesse período aí, em que os grandes dirigentes já tinham sido todos presos, aí eles começaram a perseguição na base, porque também tinha a infiltração em todo canto, em todo trabalho que você fazia (...) O que foi bom é que naquele momento a gente teve um apoio muito grande da Igreja Progressista. Porque a igreja também fazia um trabalho que chamava de Comunidade de Base e a gente entrou nessas comunidades de base... Para ter essa cobertura da Igreja, pra continuar fazendo o trabalho social que fazíamos e, inclusive, no trabalho como professor... Foi quando a gente começou a multiplicar (mesmo) professores para botar naqueles bairros de periferia todinhos, nas favelas e tal, porque através da alfabetização... Você não só alfabetizava o adulto, pois ele precisava aprender a ler, a escrever, que era fundamental pra ele, mas você também politizava, conscientizava...

Efigênia ressalta o papel da sua mãe e dos seus irmãos na sua vida. Além da importância que a mãe dava aos estudos, ela apoiava seus filhos nas causas que abraçaram em relação à efetiva militância política (além de Efigênia, uma irmã e irmãos envolveram-se em movimentos sindicais). Sobre sua genitora, a professora assim a descreveu: 
Era uma pessoa da roça, era uma mulher do interior, mas era uma pessoa muito sensível... Ela apoiava muito a gente. Meu pai nunca apoiou, meu pai era filho de espanhol, veio para o Brasil fugido da Guerra Espanhola, então, minha filha, ele tinha horror, horror!

Percebemos o quanto da experiência militante é marcante na fala e nas expressões de Efigênia. Quando se referiu ao período de três anos na prisão, várias vezes lembrou que uma das formas de sobreviver e continuar forte dentro do cárcere foi o coletivo que construiu com as outas companheiras da ala em que se encontrava no presídio. Segundo a depoente, ali havia uma enorme troca de conhecimentos e um seguro compartilhamento de experiências. Afirmou: "Então, a gente aproveitou esse tempo também para estudar. Que a gente acreditava que um dia a gente ia fazer a Revolução e que esse país ia ser diferente... A gente sonhava. A gente sonhava com isso, um dia a gente vai sair daqui e vai continuar". Em relação às experiências como professora, foi outra depoente que destacou a influência da pedagogia freiriana ${ }^{18}$.

Mulher e militante, fez questão de afirmar que prefere ser chamada de educadora, e não de professora. Para ela, ser educadora traz em si uma dimensão mais ampla e completa dos atos de educar e de se reinventar, de aprender ao educar, sendo um "processo infindo de construção do ser". Em relação ao legado como educadora, percebe-se uma ênfase na sua dedicação à educação de jovens e adultos, militância que foi constante em sua vida. Sua atuação começou em Minas e continuou em Pernambuco, desde sua chegada no início dos anos de 1980. Para ela a educação é uma arma poderosa para a libertação do povo oprimido, notadamente das pessoas que habitam o meio rural, lugar por excelência da sua atuação profissional.

Finalmente, diferentemente da sua conterrânea Efigênia, a mineira Maria Céres Pimenta, como vimos, nunca almejou ser professora. Queria, até por ser uma imposição da família e da sociedade à época, distanciar-se daquilo que seria a profissão destinada às mulheres de sua geração. A expansão das camadas médias da população no período permitiu não apenas maior inserção no mercado de trabalho, mas sobretudo a expansão do ensino superior brasileiro, o que significou, parta as mulheres, a possibilidade de não repetirem passivamente a tradição. Ainda quando estudante do curso de serviço social na PUC de Minas Gerais, exerceu a função de

18 Esse aspecto, que não será desenvolvido aqui, merece mais estudos. Em um momento no qual o tecnicismo educativo preponderava, e ainda era tímido o debate sobre pedagogias alternativas ou sobre o papel ideológico e/ou emancipatório que a educação representava, o legado de Paulo Freire parece ter-se tornado um farol, se não o único, para quem pensava a educação em chave mais crítica. Some-se a esse aspecto o tema do nacionalismo, que também impactava muitos dos movimentos de esquerda. Alguns grupos proclamavam claramente a revolução e a derrota do capitalismo. Outros, mais reformistas, moviam-se em torno de uma agenda que reivindicava direitos, igualdade, justiça etc. de maneira mais difusa. Esse aspecto refletia-se também nos diversos debates sobre a cultura, pois o nacional-popular era uma chave interpretativa importante no período, no meio intelectual, incluindo o meio estudantil. 
professora apenas como forma de subsistência. Sua inserção na docência universitária ocorreu em 1975, quando foi convidada para compor o grupo que discutiria a criação do curso de serviço social na UFMG. Destacou: "Eu não tinha atestado de bons antecedentes, mas ele [o reitor ${ }^{19}$ autorizou. Segundo me disseram, ele olhou para mim e depois falou para a pessoa assim: 'Não tem sentido aquela mocinha ser perigosa desse jeito' [risos]”. Segundo a depoente, por questões políticas o curso de serviço social não foi criado. Por isso ela se tornou professora do Departamento de Comunicação Social.

Mesmo nunca desejando ser professora, infere-se que Maria Céres tenha construído uma exitosa trajetória profissional na área da docência e da educação. Como Secretária Municipal de Educação de Belo Horizonte no fim dos anos de 1990 a 2000, teria protagonizado ações que ela, sem modéstia, definiu como "pioneiras" na educação brasileira, como a criação do Bolsa Escola e do ensino fundamental de nove anos. Ao longo do depoimento, percebe-se o quanto a lembrança da trajetória profissional nas áreas do ensino, da pesquisa e da gestão traz satisfação por tudo o que ela considera que foi feito e conquistado. Esse é um dos dilemas da memória: o quanto ela pode ser produzida de maneira a apaziguar nossos dilemas em relação às escolhas do passado e do presente. Mas também disto ela é feita: de avanços, hesitações, omissões, escolhas, lacunas, excessos.

\section{COSTURANDO MEMÓRIAS}

A memória só faz sentido depois do esquecimento? Milton Hatoum (2017, p. 234)

Ao procurarmos entrelaçar as histórias das quatro educadoras, podemos afirmar que as suas trajetórias possuem aspectos em comum. Não é demais lembrar, com Halbwachs (2006), que a memória coletiva se produz pelo entrecruzamento de experiências compartilhadas, muitas delas individuais. Embora haja o compartilhamento de experiências próprias ao período vivido por essas mulheres, cada uma tem uma percepção própria do que aconteceu, ou seja, uma memória com características singulares. Assim, a subjetividade e as experiências individuais não podem nem devem ser desprezadas na construção da memória e, consequentemente, na produção da História. Mas o que define o imperativo ético da produção e da manutenção da memória é sua potência para falar de tempos, espaços e experiências que dão sentido à vida em comum; logo permitem afirmar ou solapar a existência da vida política. Desse modo, os depoimentos aqui apresentados, longe de enaltecer ou refutar o valor da experiência individual, representam um indicativo poderoso de um tempo no qual, para muitas pessoas, educar transcendia a dimensão técnica e instrumental para converter-se em parte constitutiva da luta política. A relevância desse tipo de registro está na sua potência para entendermos que muito daquilo que está presente

19 O convite foi feito pela professora Maria Lisboa de Oliveira, assessora do então reitor, professor Eduardo Osório Cisalpino, que esteve à frente da universidade entre 1974 e 1978. 
na pauta conservadora e reacionária dos tempos recentes já foi material combatido pela experiência de mulheres que compreenderam que a educação é mais do que um direito, é condição de existência de uma vida digna.

Entre as quatros narradoras, destacamos a singularidade das experiências de Efigênia Oliveira. Sua história diferencia-se das demais, visto que a sua militância não se iniciou na escola normal ou na universidade, mas sim no chão da escola do meio rural e no sindicalismo fabril, em experiências que marcariam toda a sua trajetória profissional e pessoal. Mulher, trabalhadora fabril, militante. Se não incomum, trata-se de um caso poucas vezes visibilizado pela História da Educação. Mas os quatro casos aqui explorados contam de experiências de mulheres militantes, nunca ou raramente lembradas pela historiografia, mesmo muitos anos depois da publicação do clássico de Michele Perrot que alertava sobre os excluídos - e as excluídas - da História, ou de a noção de gênero ter-se configurado como uma das categorias mais visitadas nas pesquisas em Educação no Brasil. Elas foram mulheres, trabalhadoras, militantes e prisioneiras em um período dos mais obscuros da história brasileira. Testemunhas de que o arbítrio que se abateu sobre este país não se deu sem que houvesse toda forma de resistência, mesmo aquela que articulava a educação com a vida.

As histórias de vida aqui apresentadas fazem-nos vislumbrar o entrelaçamento de vidas construídas sobre uma teia de sociabilidade, na qual se encontram a instituição familiar, instituições escolares públicas e privadas, a instituição religiosa (Igreja católica), entidades e partidos políticos, universidade e agentes a serviço do estado ditatorial. Nessas vidas percebemos pontos que se aproximam ou se distanciam, mas por meio das análises realizadas sobre suas narrativas encontramos um ponto convergente nessas trajetórias, que julgamos constituir um legado para a história das mulheres no Brasil. Trata-se da consciência e da permanência do compromisso com a educação e com a sociedade, da luta pela justiça social e por uma sociedade solidária e mais humana, o que não é pouco em um momento de extremado individualismo. Nesse sentido, a militância da juventude parece ter-se tornado marca indelével das suas experiências como professoras, educadoras que creram na transformação da juventude e no seu papel na transformação da sociedade.

Como só ocorrer em toda vida ordinária, as histórias narradas são permeadas de teimosias, desafios, lutas, derrotas e conquistas. Certamente, também de lapsos. No entanto, no caso das quatro mulheres aqui apresentadas, momentos traumáticos vividos na juventude não retiraram delas o sorriso nem o semblante leve e ao mesmo tempo altivo que marca a sua experiência de envelhecimento. São mulheres que conquistaram seus espaços profissionais, constituíram famílias, contribuíram de forma aguerrida para garantir a sobrevivência da democracia e estavam repletas de vigor para refazerem suas vidas no período da redemocratização. Que, sobretudo, ajudam a elaborar o passado e atualizar a memória deste país pelo compartilhamento das suas nada desprezíveis experiências como jovens, educadoras, militantes, mulheres.

Contra todas as formas de apagamento da história e da memória, concluímos lembrando que sem memória não há justiça. Sem justiça, jamais haverá uma educação que seja um ato de libertação. 


\section{REFERÊNCIAS}

ALBERTI, V. História oral: a experiência do CPDOC. Rio de Janeiro: FGVCPDOC, 1990.

ARAÚJO, F. M. L. Dos espaços escolares e de militância política à sala de aula: percursos formativos e experienciais de educadoras brasileiras (1950-2000). 2018. Relatório (Pós-doutorado em Educação) - Programa de Pós-Graduação em Educação: Conhecimento e Inclusão Social, Faculdade de Educação, Universidade Federal de Minas Gerais, 2018.

BENJAMIN, W. Magia e técnica, arte e política. São Paulo: Brasiliense, 1994.

BRAGHINI, K. Juventude e pensamento conservador no Brasil. São Paulo: EDUC; FAPESP, 2015.

BRAGHINI, K. A história dos estudantes “excedentes" nos anos 1960: a superlotação das universidades e um "torvelinho de situações improvisadas". Educar em Revista. Curitiba, n. 51, p. 123-144, jan./mar. 2014. https://doi.org/10.1590/S0104-40602014000100009 CARDOSO, I. A geração dos anos de 1960: o peso de uma herança. Tempo Social, São Paulo, v. 17, n. 2, p. 93-107,2005. https://doi.org/10.1590/S0103-20702005000200005 CASTRO, M. C. S. Entrevista realizada pelo autor. Belo Horizonte, 3 maio 2018. CAVALCANTE, M. R. Entrevista realizada por Fátima Maria Leitão Araújo. Fortaleza, 13 nov. 2015.

COLLING, A.M.A resistência da mulher à ditadura militar no Brasil. Rio de Janeiro: Record; Rosa dos Tempos, 1997.

COLLING, A. M. As mulheres e a Ditadura Militar no Brasil. In: CONGRESSO LUSO BRASILEIRO DE CIÊNCIAS SOCIAIS, 8., 2004, Coimbra. Anais [...]. Coimbra: Universidade de Coimbra, 2004.

COMISSÃO DA VERDADE EM MINAS GERAIS. Relatório final/Governo do Estado. Núcleo de História Oral da FAFICHE-UFMG. Belo Horizonte: COVEMG, 2017. v. 1-5. [Acervo de entrevistas].

GARRIDO, F. A. Z. El trabajo docente durante la dictadura cívico-militar en Chile (1973-1990): una mirada desde las políticas públicas educacionales. História da Educação, Santa Maria, v. 24, 2020. https://doi.org/10.1590/2236-3459/92711

GERMANO, J. W. Estado militar e educação no Brasil: 1964-1985. São Paulo: Cortez, 1993.

HALBWACHS, M. A memória coletiva. São Paulo: Centauro, 2006.

HATOUM, M. A noite da espera. São Paulo: Companhia das Letras, 2017.

KAUFMANN, C. Dictadura y educación. Salamanca: FahrenHouse, 2017. t. I.

LENHARO, A. Sacralização da política. 2. ed. Campinas: Papirus, 1986.

MARTINS, M. C. Reflexos reformistas: o ensino das humanidades na ditadura militar brasileira e as formas duvidosas de esquecer. Educar em Revista, Curitiba, n. 51, jan./ mar. 2014. https://doi.org/10.1590/S0104-40602014000100004 
MONTEIRO, H. S. Entrevista realizada por Fátima Maria Leitão Araújo. Fortaleza, 05 de abril de 2017.

MOTTA, R. P. As universidades e o regime militar. Rio de Janeiro: Zahar, 2014.

OLIVEIRA, E. M. Entrevista realizada por Fátima Maria Leitão Araújo. Cabo de Santo Agostinho, Pernambuco, 4 dez. 2017.

PINSKY, C. Estudos de gênero e história social. Revista Estudos Feministas, Florianópolis, v. 17, n. 1, p. 159-189, abr. 2009. https://doi.org/10.1590/S0104026X2009000100009

POLLAK, M. Memória e identidade social. Estudos Históricos, Rio de Janeiro, v. 5, n. 10, p. 200-212, 1992. Disponível em: http://www.pgedf.ufpr.br/memoria\%20e\%20 identidadesocial\%20A\%20capraro\%202.pdf. Acesso em: 1 dez. 2021.

POLLAK, M. Memória, esquecimento e silêncio. Estudos Históricos, Rio de Janeiro, v. 2, n. 3, p. 3-15, 1989. Disponível em: https://bibliotecadigital.fgv.br/ojs/index.php/ $\mathrm{reh} /$ article/view/2278. Acesso em: $1 \mathrm{dez} .2021$.

REIS FILHO, D. A; MORAES, P. 1968: a paixão de uma utopia. 2. ed. Rio de Janeiro: Fundação Getulio Vargas, 1998.v. 1.

REIS FILHO, D. A.; MOTA, R. P. S. Ditadura e democracia no Brasil: 50 anos depois - do golpe de 1964 à Constituição de 1988. Rio de Janeiro: Zahar, 2014.

REIS FILHO, D. A.; MOTA, R. P. S. 1968: O curto ano de todos os desejos. Tempo Social, São Paulo, n. 10, p. 25-35, out. 1998.

ROSA, S. O. Mulheres: ditadura e memórias - Não imagino que precise ser triste para ser militante. São Paulo: Intermeos; FAPESP, 2013. (Coleção Entregêneros).

TABORDA DE OLIVEIRA, M. A. La experiencia de una profesora escolar como posibilidad de pensar y hacer de la escuela un lugar de cultura. Trayectoria formativa de buenas prácticas educativas. Educacion Fisica y Deporte, v. 33, p. 125-161, 2014. http://doi.org/10.17533/udea.efyd.v33n2a06

TABORDA DE OLIVEIRA, M. A. Educação Física escolar e civil-ditadura militar no Brasil (1968-1984): entre a adesão e a resistência e outros estudos. Curitiba: Editora da UFPR, 2018.

THOMPSON, E. P. A miséria da teoria ou um planetário de erro: uma crítica ao pensamento de Althusser. Rio de Janeiro: Zahar, 1981.

THOMPSON, P. A voz do passado história oral. Rio de Janeiro: Paz e Terra, 1992.

WILLIAMS, R. La larga revolución. Buenos Aires: Nueva Visión, 2003.

\section{SOBRE OS AUTORES}

Fátima Maria Leitão Araújo é doutora em educação brasileira pela Universidade Federal do Ceará (UFC). Professora da Universidade Estadual do Ceará (UECE).

E-mail: fatima.leitao@uece.br 
Marcus Aurelio Taborda de Oliveira é doutor em história e filosofia da educação pela Pontifícia Universidade Católica de São Paulo (PUC-SP). Professor da Universidade Federal de Minas Gerais (UFMG). E-mail:marcustaborda@uol.com.br

Conflitos de interesse: Os autores declaram que não possuem nenhum interesse comercial ou associativo que represente conflito de interesses em relação ao manuscrito.

Financiamento: Conselho Nacional de Desenvolvimento Científico e Tecnológico (CNPq), na modalidade bolsa de produtividade n. 307361/2018-7; Programa de Excelência Acadêmica da Coordenação de Aperfeiçoamento de Pessoal de Nível Superior (PROEX/ CAPES).

Contribuições dos autores: Escrita - Primeira Redação, Escrita - Revisão e Edição, Metodologia: Araújo, F. M. L.; Taborda de Oliveira, M. Análise Formal, Curadoria de Dados: Araújo, F. M. L. Conceituação, Investigação: Taborda de Oliveira, M.

Recebido em 24 de agosto de 2020 Aprovado em 9 de abril de 2021 